\title{
Patiëntenvoorlichting PV 38. Melanoom
}

Een melanoom is een kwaadaardige woekering van pigmenthoudende cellen van de huid en de slijmvliezen. Melanomen komen vooral op de huid ; daarbij is overmatige blootstelling aan zonlicht de belangrijkste oorzaak. Melanomen komen zelden in het mondslijmvlies voor. De oorzaak van een in de mond voorkomend melanoom is volledig onbekend. Mondmelanomen komen vooral op middelbare en oudere leeftijd voor. Meestal is sprake van een blauwe of bruine gepigmenteerde zwelling van het mondslijmvlies, soms zonder verdere klachten. Om de diagnose met zekerheid te kunnen stellen is het nodig een klein weefselstukje te verwijderen voor onderzoek door de patholoog. Bij de behandeling wordt vrijwel altijd gebruikgemaakt van operatieve verwijdering, soms gevolgd door bestraling. Een enkele maal wordt gebruikgemaakt van medicijnen (chemotherapie). Na operatieve verwijderin blijkt het gezwel soms terug te keren. Ook kan sprake zijn van uitzaaiingen naar de lymfeklieren in de hals en soms ook naar andere plaatsen in het lichaam. De kansen om te genezen hangen vooral af van de grootte en de dikte van het gezwel. Zoals voor kanker in het algemeen geldt, gaat het bij sommige patiënten doe voor een mondmelanoom behandeld zijn beter dan (statistisch) was voorspeld, terwijl het bij andere juist slechter gaat, zonder dat daar een verklaring voor is te geven.

\section{Wat kunt u zelf doen?}

Bij een mondmelanoom kunt U zelf niets doen. Het onbehandeld laten, kan tot een zeer onaangename en onbeheersbare situatie leiden.
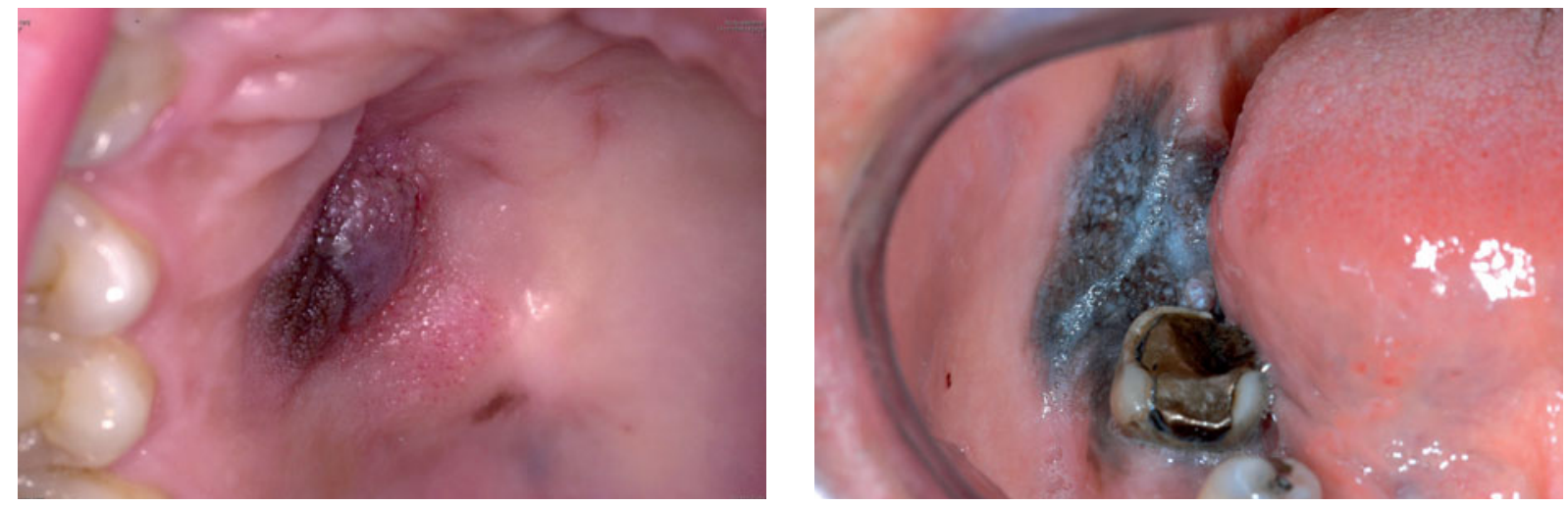